See discussions, stats, and author profiles for this publication at: https://www.researchgate.net/publication/ 320340078

\title{
Variable Levels of Resistance of Soybean Genotypes on the Performance of Euschistus heros (Hemiptera: Pentatomidae)
}

Article in Journal of Economic Entomology · October 2017

DOI: $10.1093 / \mathrm{jee} / \mathrm{tox} 254$

CITATION

1

7 authors, including:

\section{Efrain Souza}

Universidade Estadual Do Tocantins

9 PUBLICATIONS 69 CITATIONS

SEE PROFILE

José Paulo Franco Bentivenha

Ihara

25 PUBLICATIONS 112 CITATIONS

SEE PROFILE

Some of the authors of this publication are also working on these related projects:

Resistance of soybean to insects View project

Project Resistencia Tuta; Interação tritrofica View project
Vinícius Canassa

São Paulo State University

13 PUBLICATIONS 40 CITATIONS

SEE PROFILE

Edson L. L. Baldin

São Paulo State University

116 PUBLICATIONS 734 CITATIONS

SEE PROFILE 


\title{
Variable Levels of Resistance of Soybean Genotypes on the Performance of Euschistus heros (Hemiptera: Pentatomidae)
}

\author{
Efrain S. Souza, ${ }^{1}$ Vinícius F. Canassa, ${ }^{2}$ José P. F. Bentivenha, ${ }^{3,5}$ Edson L. L. Baldin, ${ }^{2}$ \\ Caroline G. Pierozzi, ${ }^{2}$ André L. Lourenção, ${ }^{4}$ and Luiz E. R. Pannuti ${ }^{2}$
}

\begin{abstract}
'Department of Entomology, Tocantins State University, P0 Box 173, Palmas, Tocantins 77020-122, Brazil, 2Department of Crop Protection, College of Agronomic Science, São Paulo State University, P0 Box 237, Botucatu, São Paulo 18610-307, Brazil, ${ }^{3}$ Department of Entomology and Acarology, Luiz de Queiroz College of Agriculture, University of São Paulo, Piracicaba, São Paulo 13418-900, Brazil, ${ }^{4}$ Agronomic Institute of Campinas, Campinas, São Paulo 13012-970, Brazil, and ${ }^{5}$ Corresponding author, e-mail: jpbentivenha@gmail.com
\end{abstract}

Subject Editor: John Trumble

Received 30 June 2017; Editorial decision 14 August 2017

\begin{abstract}
The Neotropical brown stink bug Euschistus heros (Fabr.) (Hemiptera: Pentatomidae) is one of the major soybean pests in South America. This species is responsible for high levels of infestation, causes critical damage to seeds, it is associated with leaf retention on plants, and it is extremely difficult to manage. Host plant resistance is a notable technique to assist in reducing the stink bug population in soybean crops. The antibiosis resistance of soybean genotypes to $E$. heros was evaluated in laboratory. Genotypes L1-1-01, 'IAC 100', 'IAC 23', and 'Coodetec 208 ' increased the length of nymphal developmental time. PI 274453 and PI 227687 reduced egg viability and also adult body weight. PI 274454, 'IAC 19', PI 227687, and PI 229358 led to low nymphal viability. These results suggest that these genotypes may be useful in soybean breeding programs that focus on the development of genotypes resistant to $E$. heros.
\end{abstract}

Key words: neotropical brown stink bug, host plant resistance, antibiosis, Glycine max

Among the soybean stink bug complex, the Neotropical brown stink bug Euschistus heros (Fabr.) (Hemiptera: Pentatomidae) is one of the most important pests. It has received considerable attention due to severe damage and yield losses caused (Corrêa-Ferreira and Azevedo 2002), and its high abundance compared to other stink bug species (Kuss 2012). In the past several years, E. heros has expanded throughout Brazil (Smaniotto and Panizzi 2015) and reaching some areas in Argentina (Saluso et al. 2011). The increased occurrence of E. heros is related to its great adaptation to regions with high temperatures and high diversity of host plants (Smaniotto and Panizzi 2015). Also, annual crops used in succession in the Brazilian agricultural systems, and its capacity for hibernation has played a significant role in the spread of this insect (Panizzi 2007)

Euschistus heros can cause irreversible injury to soybean plants by sucking out nutrients of seeds, thereby decreasing their quality and quantity (Depieri and Panizzi 2011, Silva et al. 2012). The pest is also related to pathogen infection of pods, e.g., the fungus Nematospora coryli (Peglion), a causative organism of yeast-spot disease (Panizzi 1997). In general, attacked seeds decrease in size, appear corrugated, and dark in color; show decreased oil levels; and show increases in protein content (Degrande et al. 2007). In addition, injuries provoked by the stink bug are related to the physiological disturbance of soybean maturation, a phenomenon known in Brazil as ‘crazy soybean' (Sosa-Gómez and Moscardi 1995).

The management of stink bug populations on soybean is mainly based on preventive chemical applications (Bueno et al. 2013) without proper pest monitoring. Excessive use of chemical products promotes the selection of stink bugs resistant to active ingredients, decreases populations of natural enemies, negatively impacts natural environments, and poses a risk to human health (Sosa-Gómez and Silva 2010, Bueno et al. 2011, Belo et al. 2012). It is, therefore, crucial to explore effective and less aggressive alternative management methods based on integrated pest management programmes.

Increasing host plant resistance is a valuable management method (Smith and Clement 2012) with the following advantages: nonresidual accumulation in food, no environmental pollution, action at all pest infestation levels, no interference with other agricultural practices, easy accessibility by farmers, and a reduction in pest populations to levels that do not cause economic damage (Lara, 1991, Smith 2005). 
Due to the potential injuries provoked by E. heros, its distribution and predominance over other species of stink bugs, and reported resistance of soybean genotypes against the stink bug complex (Souza et al. 2012, 2015; Silva et al. 2013, 2014), studies evaluating the resistance of soybean genotypes against E. heros are crucial. In this work, we assessed several biological parameters of E. heros on 17 soybean genotypes of different maturity groups, with the aim of identifying potential antibiosis.

\section{Materials and Methods}

To evaluate the biological performance of E. heros in different genotypes under laboratory conditions (temperature $[\mathrm{T}]=26 \pm 2^{\circ} \mathrm{C}$, relative humidity $[\mathrm{RH}]=65 \pm 10 \%$, photoperiod $=14 \mathrm{~h}$ ), we adopted the methodology proposed by Silva et al. (2007). Assessing the duration of each nymphal instar in different photoperiods, Mourão and Panizzi (2000)concluded that E. heros nymphs in the second, third, and fourth instars fed with immature pods from the susceptible genotype 'Paraná' (Rossetto et al. 1986) took 6.0, 5.3, and $5.9 \mathrm{~d}$ to complete each instar, respectively, under a photoperiod of $10 \mathrm{~h}$. When fed under $14 \mathrm{~h}$ of light, nymphs took 4.6, 4.8, and $5.4 \mathrm{~d}$ in each instar, respectively, indicating that nymphal development is related to the photoperiod used. For this reason, we used a daily photoperiod of $14 \mathrm{~h}$, at which each instar is influenced by the soybean genotype only.

The duration of the nymphal stadia (N2, N3, N4, and N5), developmental time (egg - adult), adult body weight ( $24 \mathrm{~h})$, adults longevity, and mortality (\%) in each instar, and nymphal and egg viability were assessed. The genotypes and their genealogy used are described in Table 1.

\section{Euschistus heros Rearing}

Stock rearing of E. heros was performed in the laboratory using egg masses obtained from the Laboratório de Biologia de Insetos, Escola
Superior de Agricultura 'Luiz de Queiroz', Piracicaba, SP. Eggs were conditioned in Petri dishes $(6 \mathrm{~cm} \varnothing)$ containing filter paper at the bottom and a small portion of cotton soaked in distilled water (Costa et al. 1998). After hatching, nymphs were maintained in Petri dishes until they reached the second instar and then were released into plastic containers $(40 \times 22 \times 14 \mathrm{~cm})$ lined with filter paper. Bean pods, Phaseolus vulgaris (L.) (Fabales: Fabaceae) and peanut seeds, Arachis hypogaea (L.) (Fabales: Fabaceae) were used as food sources along with a cotton portion soaked with distilled water in a plastic container $(50 \mathrm{ml})$. A layer of solid Vaseline was applied at the upper edge to prevent the insects to escape, using a lid adapted with voile tissue for aeration. Pieces of raw cotton were placed in the plastic containers to serve as surfaces for clutches; they were collected daily to avoid the consumption of eggs by the stink bugs (Panizzi 1991). Every 3 d, foods were replaced, and the food and water containers were cleaned to avoid microbial contamination.

Periodically, adults of E. heros were collected from a soybean field with a beat cloth $(1.0 \times 0.5 \mathrm{~m})$ and placed into the containers to improve the colony vigor by avoiding degeneration through endogamy. During field collections, we opted for crop areas with different genotypes from those used in this study, thereby avoiding pre-imaginal conditioning (Smith 2005).

\section{Antibiosis Bioassays}

For the antibiosis bioassay, egg masses $(24 \mathrm{~h})$ were collected from the stock rearing and placed in Petri dishes $(9 \mathrm{~cm})$ lined with filter paper. After hatching, as nymphs reached the second instar, they were placed in pairs in Petri dishes lined with filter paper, with a portion of cotton soaked in distilled water, and a pod of one of the assessed genotypes. The pods were collected from soybean plants cultivated in a greenhouse, and the pod-filling was standardized in stage R5.4/ R6 (Fehr and Caviness 1977). Each Petri dish represented a replicate, totaling 25 replicates per genotype, with two stink bugs per

Table 1. Soybean genotypes used, grouped according to phenology, genealogy, and resistance history

\begin{tabular}{|c|c|c|c|}
\hline Maturity & Genotype & Genealogy & Resistance history \\
\hline \multirow[t]{6}{*}{ Early } & 'IAC 17' & D72-9601-1 × 'IAC 8' & Antixenosis to B. tabaci biotype B (Silva et al. 2012b, Valle and Lourenção 2002) \\
\hline & 'IAC 23' & BR-6 x IAC 83-23 & Resistant to insects (Miranda et al. 2003) \\
\hline & PI 171451 & Japan & Resistant to stink bugs (Rossetto et al. 1986, Silva et al. 2013) \\
\hline & PI 229358 & Tokyo, Japan & Resistant to stink bugs (Rossetto et al. 1986, Silva et al. 2013) \\
\hline & D $75-10169$ & $\begin{array}{l}\text { 'Govan’ } \times(\text { F4 'Bragg' } \times \text { PI } \\
\text { 229358) }\end{array}$ & $\begin{array}{l}\text { Multiple insect resistance in its genealogy (Silva et al. 2013b); resistant to } \\
\text { B. tabaci biotype B (Valle and Lourenção 2002) }\end{array}$ \\
\hline & 'Coodetec 208' & OC-4 × Williams 20 & Commercial susceptible (Silva et al. 2013) \\
\hline \multirow[t]{6}{*}{ Semi-early } & 'IAC 18' & D72-9601 × 'IAC 8' & Tolerant to complex stinkbug (Lourenção et al. 2000) \\
\hline & 'IAC 24' & IAC $80-1177 \times$ IAC $83-288$ & Antixenosis to B. tabaci biotype B (Silva et al. 2012b, Valle and Lourenção 2002) \\
\hline & 'IAC 100’ & 'IAC-12' $\times$ IAC 78-2318 & Antibiosis to P. guildinii (Silva et al. 2013b) \\
\hline & IAC 74-2832 & 'Hill' × PI 274454 & Antibiosis to P. guildinii (Silva et al. 2013b) \\
\hline & IAC 78-2318 & D72-96-1 × IAC 73-227 & $\begin{array}{l}\text { Resistant to stinkbugs and Crocidosema aporema (Rossetto et al. 1986; } \\
\text { Lourenção et al. 1987, 1989; Silva et al. 2013) }\end{array}$ \\
\hline & PI 227687 & Okinawa, Japan & $\begin{array}{l}\text { Resistant to stinkbugs and Chrysomelidae defoliators (Rossetto et al. 1986, } \\
\text { Lourenção et al. 1989, Silva et al. 2013) }\end{array}$ \\
\hline \multirow[t]{5}{*}{ Late } & 'IAC 19' & D72-9601-1 × 'IAC 8' & $\begin{array}{l}\text { Antixenosis to B. tabaci biotype B (Valle and Lourenção 2002), antibiosis to } \\
\text { P. guildinii (Silva et al. 2013) }\end{array}$ \\
\hline & PI 274453 & Okinawa, Japan & $\begin{array}{l}\text { Resistant to stinkbugs (Rossetto et al. 1986, Lourenção et al. 1989, Silva et al. } \\
\text { 2013) }\end{array}$ \\
\hline & PI 274454 & Okinawa, Japan & $\begin{array}{l}\text { Resistant to stinkbugs and Omiodes indicata (Rossetto et al. 1986, Lourenção } \\
\text { et al. 1989, Silva et al. 2013) }\end{array}$ \\
\hline & L $1-1-01$ & BR-6 x× 'IAC 100’ & Antibiosis to P. guildinii (Silva et al. 2013) \\
\hline & 'Conquista' & Lo76-44842 × Numbaíra & Commercial susceptible (Silva et al. 2013) \\
\hline
\end{tabular}

Sources: Lourenção and Miranda 1987; Valle and Lourenção 2002; McPherson and Buss 2007; McPherson et al. 2007; Silva et al. 2012, 2013, 2014; Souza et al. 2014. 
Petri dish, in a completely randomized design. Second-instar nymphs were utilized because of high-mortality/gregariousness behavior of first-instars and because they do not feed (Panizzi and Silva 2009).

Every $2 \mathrm{~d}$, the pods were changed, and the cotton portion was wetted with distilled water or changed as necessary. The filter paper was changed every $5 \mathrm{~d}$ to avoid fungal growth. Dead insects and exuviae were removed with a metal clip during the evaluations. Insects were inspected daily to assess development.

When the stink bugs reached the adult stage, 10 insects from each genotype were carefully individually deposited into a Petri dish and weighed on an analytical scale (Marte AY220, accuracy $0.0001 \mathrm{~g}$ ). Subsequently, adults were maintained in Petri dishes, fed with pods to allow evaluate longevity on each genotype.

To assess egg viability, 120 eggs ( $24 \mathrm{~h}$ ) were placed in plastic arenas (22 $\mathrm{cm} \varnothing$ and $20-\mathrm{cm}$ height) lined with filter paper, covered with voile tissue, and the bottom surface lined with a disc of filter paper with a cotton portion soaked with distilled water and 10 soybean pods (R5) of the respective genotype. Every $2 \mathrm{~d}$, the arenas were cleaned, and the pods changed, removing exuviae and dead insects. When the stink bugs reached adulthood, pieces of raw cotton were placed in the arenas to serve as the oviposition surface (Silva and Panizzi 2007). All eggs were collected, recorded, and placed in Petri dishes $(3 \mathrm{~cm} \varnothing)$ for hatching and evaluation of egg viability. To measure this parameter, eight Petri dishes (containing egg masses) were selected per genotype, corresponding to eight replicates.

\section{Statistical Analyses}

Data were subjected to an analysis of variance, with normality assessed using the Shapiro-Wilk test and homoscedasticity through Levene's test. An LSD test $(P \leq 0.05)$ was used to compare the mean values of biological parameters using the statistical software PROC MIXED-SAS 9.2 (SAS Software 2001).

\section{Results}

The average incubation period of the eggs was $6.4 \mathrm{~d}$, with $3.1 \mathrm{~d}$ for the first nymphal stage. The genotypes 'IAC 100' (6.5 d) and L 1-101 (6.2) prolonged the duration of the second stadium (Table 2). In contrast, 'IAC 18' (3.1) and PI 274453 (3.3) showed the lowest average duration of this stadium. Regarding third-instars, the genotypes 'IAC 19' (9.8), 'Coodetec 208' (9.0), 'Conquista' (8.9), and L 1-101 (8.5) prevented development, whereas PI 274454 (3.5), 'IAC 17' (4.2), 'IAC 18' (4.3), PI 274453 (4.4), and 'IAC 24' (4.7) were more suitable for the nymphs. In the fourth stadium, PI 274453 (8.2), 'IAC 100' (7.9), PI 227687 (7.8), and 'IAC 23' (7.7) delayed development compared to the other genotypes. There were no differences among genotypes during the fifth stadium, with average time from 6.0 to 11.5 d. For this stadium, no data on PI 274454 was available because all nymphs died during the fourth stadium. Total nymph developmental time showed high variation among the genotypes, from 24.1 to $34.3 \mathrm{~d}$. Insects fed with L1-1-01 (34.3 d), 'IAC 100' (34.2), 'IAC 23' (31.2), and 'Coodetec 208' (30.8) showed delayed nymph developmental time. In contrast, nymphs on PI 227687, 'IAC 18', 'IAC 24', IAC 78-2318, 'IAC 17', D75-10169, and IAC 74-2832 took less time (23.3 to $27.5 \mathrm{~d}$ ) to complete development.

Nymphal viability varied from 0 to $60 \%$ (Fig. 1) and was especially low on PI 274454 (0\%), 'IAC 19' (3.3\%), PI 227687 (3.3\%), and PI 229358 (6.7\%). All genotypes caused low nymphal mortality in the second stadium, ranging from 0 to $36 \%$. Genotypes PI 274454, PI 274453, PI 229358, PI 227687, 'IAC 19', 'IAC 23', and IAC 78-2318 caused nymphal mortality above $80 \%$, whereas 'IAC 17 ' and 'IAC 18 ' mortality rate was only $40 \%$ (Fig. 2).

High variation in adult body weight $(40.8-73.5 \mathrm{mg}$ ) was also verified among the genotypes (Table 3). Genotype PI 227687 induced the lowest body weight $(40.8 \mathrm{mg})$, followed by PI 274453 (49.7 mg). In contrast, PI 229358, 'Coodetec 208', 'IAC 100',

Table 2. Means $( \pm \mathrm{SE})$ of the length of each nymphal instar and nymphal period (N1-N5) of E. heros in 17 soybean genotypes in the laboratory

\begin{tabular}{|c|c|c|c|c|c|}
\hline \multirow[t]{2}{*}{ Genotype $^{a}$} & \multicolumn{5}{|c|}{ Days $^{b, c}$} \\
\hline & Second instar & Third instar & Fourth instar & Fifth instar & $\begin{array}{l}\text { Nymphal period } \\
(\mathrm{N} 1-\mathrm{N} 5)^{d}\end{array}$ \\
\hline L 1-1-01 (L) & $6.2 \pm 0.67 \mathrm{a}(n=29)$ & $8.5 \pm 0.65 \mathrm{ab}(\mathrm{n}=23)$ & $6.2 \pm 0.57$ cde $(\mathrm{n}=18)$ & $10.6 \pm 1.33(\mathrm{n}=10)$ & $34.3 \pm 1.78 \mathrm{a}(\mathrm{n}=10)$ \\
\hline 'IAC 100’ (SE) & $6.5 \pm 0.11 \mathrm{a}(n=29)$ & $7.5 \pm 0.28 \mathrm{bc}(n=29)$ & $7.9 \pm 0.15 \mathrm{ab}(n=22)$ & $9.1 \pm 0.87(n=7)$ & $34.2 \pm 1.20 \mathrm{a}(n=7)$ \\
\hline 'IAC 23’ (E) & $3.3 \pm 0.11$ de $(n=30)$ & $6.0 \pm 0.27 \mathrm{~cd}(n=29)$ & $7.7 \pm 0.16 \mathrm{ab}(n=28)$ & $11.0 \pm 1.13(n=6)$ & $31.2 \pm 1.30 \mathrm{a}(n=6)$ \\
\hline ‘Coodetec 208’ (E) & $5.1 \pm 0.41 \mathrm{abc}(n=23)$ & $9.0 \pm 0.53 \mathrm{ab}(n=13)$ & $5.2 \pm 0.47$ ef $(n=11)$ & $9.6 \pm 0.44(n=9)$ & $30.8 \pm 1.12$ a $(n=9)$ \\
\hline PI 229358 (E) & $3.5 \pm 0.11$ de $(n=49)$ & $6.0 \pm 0.41 \mathrm{~cd}(n=27)$ & $7.7 \pm 0.21 \mathrm{abc}(n=23)$ & $11.5 \pm 0.50(n=2)$ & $30.1 \pm 1.00 \mathrm{ab}(n=1)$ \\
\hline PI 171451 (E) & $5.7 \pm 0.66 \mathrm{ab}(n=24)$ & $7.2 \pm 0.55 \mathrm{bc}(n=17)$ & $7.3 \pm 0.44 \mathrm{abcd}(n=16)$ & $9.8 \pm 1.12(n=7)$ & $29.9 \pm 1.39 \mathrm{ab}(n=7)$ \\
\hline 'Conquista' (L) & $4.2 \pm 0.18$ bcde $(n=27)$ & $8.9 \pm 0.66 \mathrm{ab}(n=14)$ & $6.1 \pm 0.42$ de $(n=14)$ & $9.0 \pm 1.68(n=8)$ & $29.4 \pm 1.69 \mathrm{ab}(n=8)$ \\
\hline 'IAC 19’ (L) & $4.4 \pm 0.24$ bcde $(n=23)$ & $9.8 \pm 0.59$ a $(n=8)$ & $6.6 \pm 1.17$ bcde $(n=6)$ & $8.0 \pm 0.00(\mathrm{n}=1)$ & $29.1 \pm 0.00 \mathrm{ab}(n=1)$ \\
\hline IAC 74-2832 (SE) & $4.4 \pm 0.22$ bcde $(n=23)$ & $6.0 \pm 0.30 \mathrm{~cd}(n=23)$ & $6.6 \pm 0.22$ bcde $(n=22)$ & $7.0 \pm 0.54(n=16)$ & $27.5 \pm 0.88 \mathrm{~b}(n=16)$ \\
\hline D 75-10169 (E) & $4.2 \pm 0.35$ bcde $(n=28)$ & $5.8 \pm 0.39 \mathrm{~cd}(n=26)$ & $7.4 \pm 0.22 \mathrm{abcd}(n=20)$ & $7.6 \pm 0.50(n=8)$ & $27.3 \pm 1.01 \mathrm{~b}(n=8)$ \\
\hline PI 274453 (L) & $3.3 \pm 0.18$ e $(n=29)$ & $4.4 \pm 0.19$ de $(n=21)$ & $8.2 \pm 0.30 \mathrm{a}(n=16)$ & $8.6 \pm 0.78(n=8)$ & $26.9 \pm 0.64 \mathrm{~b}(n=8)$ \\
\hline 'IAC 17’ (E) & $3.3 \pm 0.18$ de $(n=29)$ & $4.2 \pm 0.28$ de $(n=29)$ & $7.8 \pm 0.17 \mathrm{ab}(n=28)$ & $8.1 \pm 0.20(n=18)$ & $23.7 \pm 0.33 \mathrm{~b}(n=18)$ \\
\hline IAC 78-2318 (SE) & $3.9 \pm 0.19$ cde $(n=30)$ & $5.7 \pm 0.22$ cde $(n=28)$ & $7.6 \pm 0.27 \mathrm{abcd}(n=21)$ & $6.5 \pm 0.72(n=6)$ & $26.6 \pm 0.67 \mathrm{~b}(n=6)$ \\
\hline 'IAC 24’ (SE) & $3.3 \pm 0.09 \mathrm{de}(n=29)$ & $4.7 \pm 0.12$ de $(n=29)$ & $7.5 \pm 0.10 \mathrm{abcd}(n=27)$ & $8.0 \pm 0.71(n=11)$ & $23.3 \pm 0.71 \mathrm{~b}(n=11)$ \\
\hline 'IAC 18' (SE) & $3.1 \pm 0.23$ e $(n=27)$ & $4.3 \pm 0.37$ de $(n=27)$ & $7.7 \pm 0.19 \mathrm{abc}(n=27)$ & $7.8 \pm 1.13(n=18)$ & $25.8 \pm 0.57 \mathrm{~b}(n=18)$ \\
\hline PI 227687 (SE) & $4.7 \pm 0.26$ abcd $(n=48)$ & $6.3 \pm 0.31 \mathrm{~cd}(n=23)$ & $7.8 \pm 0.18 \mathrm{ab}(n=11)$ & $6.0 \pm 0.00(n=1)$ & $24.1 \pm 0.00 \mathrm{~b}(n=1)$ \\
\hline PI 274454 (L) & $3.3 \pm 0.10 \mathrm{de}(n=32)$ & $3.5 \pm 0.19$ e $(n=20)$ & $4.5 \pm 0.43 \mathrm{f}(n=7)$ & - & - \\
\hline$P$ & $<0.001$ & $<0.001$ & $<0.001$ & 0.07 & $<0.001$ \\
\hline
\end{tabular}

${ }^{a} \mathrm{E}=$ early; $\mathrm{SE}=$ semiearly; $\mathrm{L}=$ late.

${ }^{b}$ Means followed by the same lowercase letter per column do not differ significantly by LSD test $(P \leq 0.05)$.

${ }^{c} n=$ number of evaluated insects;

${ }^{d} \mathrm{~N} 1=3.1 \mathrm{~d}$ summed over all genotypes. 


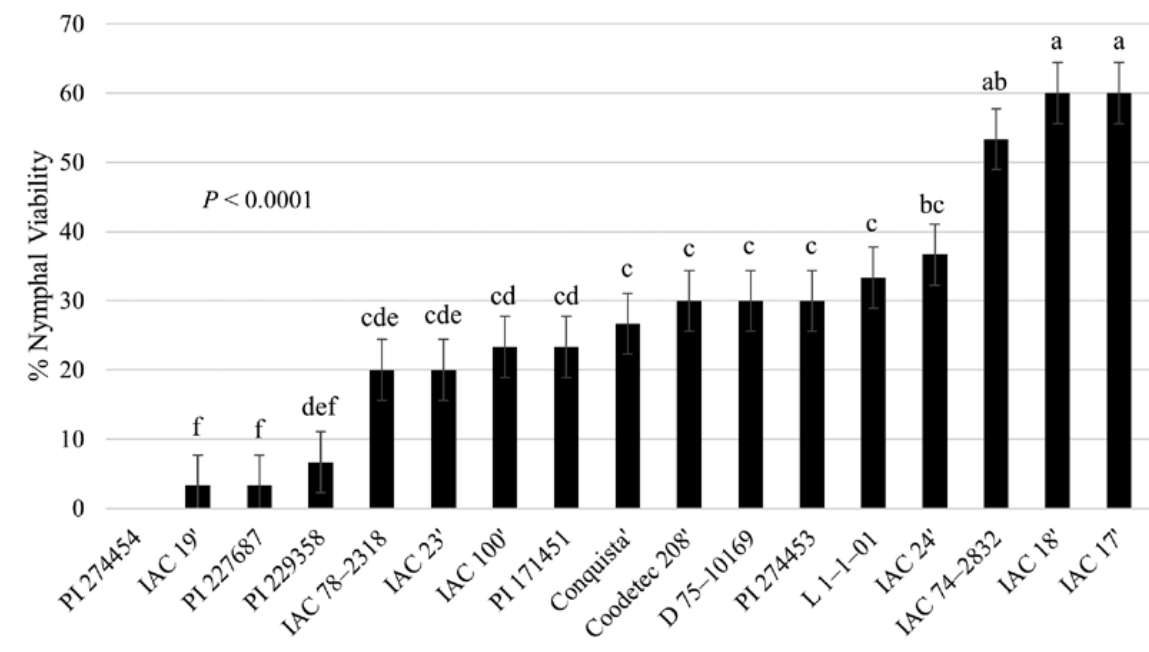

Genotypes

Fig. 1. Means $(\% \pm \mathrm{SE})$ of nymphal viability of $E$. heros in 17 soybean genotypes in the laboratory conditions.
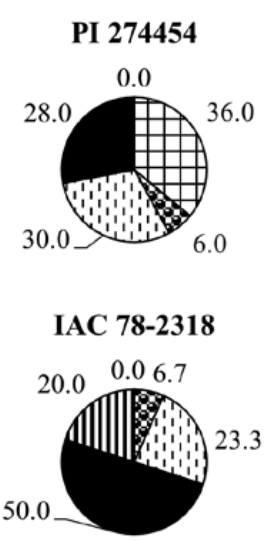

Conquista

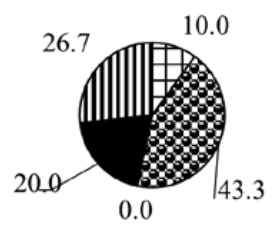

'IAC 24'

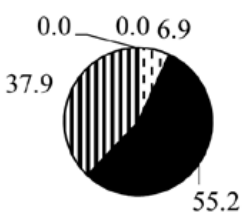

'IAC 17'

3.30 .0

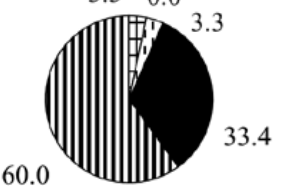

PI 227687

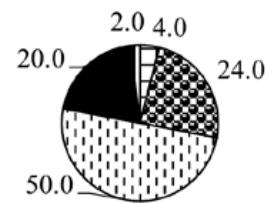

'IAC 23'

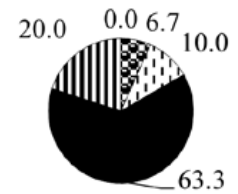

D 75-10169

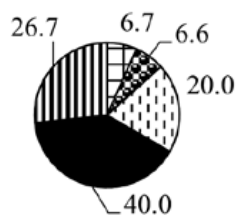

PI 274453

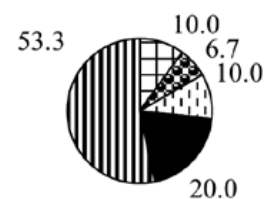

20.0
'IAC 19'

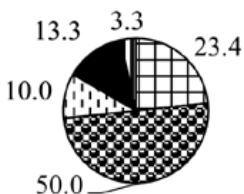

PI 171451

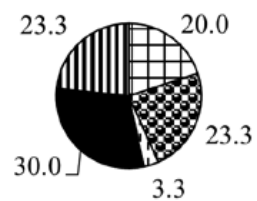

'Coodetec 208'

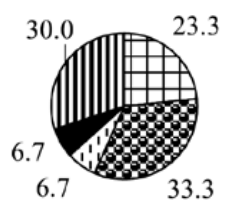

IAC 74-2832

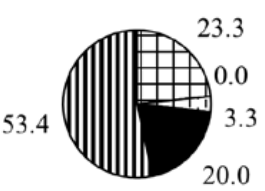

PI 229358

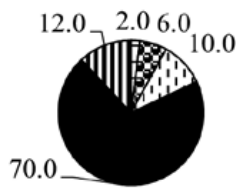

'IAC 100'

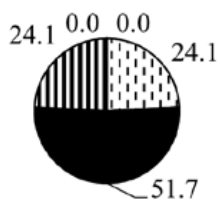

L 1-1-01

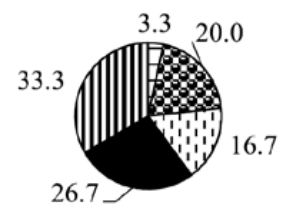

'IAC 18'

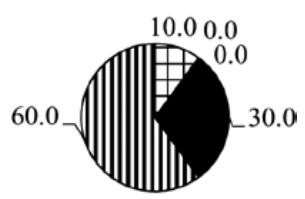

प2nd Instar

a 3rd Instar

$\square$ 4th Instar

- 5th Instar

D Adult emergence

Fig. 2. Means of nymphal mortality (\%) per instar and adult emergence of $E$. heros in 17 soybean genotypes in the laboratory. 
Table 3. Means ( \pm SE) of longevity, adult body weight, and egg viability of $E$. heros in 17 soybean genotypes in the laboratory

\begin{tabular}{|c|c|c|c|}
\hline Genotype $^{a}$ & Adult body weight $(\mathrm{mg})^{b}$ & Longevity (days) ${ }^{b, c}$ & Egg viability (\%) \\
\hline PI 229358 (E) & $73.5 \pm 2.32 \mathrm{a}(n=6)$ & $8.1 \pm 2.89(n=6)$ & $89.0 \pm 4.0 \mathrm{ab}$ \\
\hline 'Coodetec 208' (E) & $73.2 \pm 1.74$ a $(n=9)$ & $21.0 \pm 2.97(n=9)$ & $85.0 \pm 5.0 \mathrm{abc}$ \\
\hline 'IAC 100’ (SE) & $72.8 \pm 2.20 \mathrm{a}(n=10)$ & $17.7 \pm 3.25(n=7)$ & $81.0 \pm 4.0 \mathrm{abc}$ \\
\hline 'IAC 23’ (E) & $72.2 \pm 1.67 \mathrm{a}(n=6)$ & $10.0 \pm 2.85(n=6)$ & $92.0 \pm 0.4 \mathrm{a}$ \\
\hline PI $171451(\mathrm{E})$ & $71.9 \pm 3.13$ a $(n=7)$ & $11.4 \pm 2.16(n=7)$ & $90.0 \pm 4.0 \mathrm{ab}$ \\
\hline IAC 74-2832 (SE) & $71.6 \pm 2.25 \mathrm{a}(n=10)$ & $20.6 \pm 3.03(n=16)$ & $93.0 \pm 4.0 \mathrm{a}$ \\
\hline IAC 78-2318 (SE) & $70.5 \pm 3.18 \mathrm{a}(n=6)$ & $12.5 \pm 3.12(n=6)$ & $91.0 \pm 4.0 \mathrm{ab}$ \\
\hline 'Conquista' (L) & $69.9 \pm 2.04 \mathrm{a}(n=8)$ & $12.3 \pm 1.08(n=8)$ & $75.0 \pm 7.0 \mathrm{bc}$ \\
\hline D 75-10169 (E) & $67.2 \pm 3.02 \mathrm{ab}(n=8)$ & $17.3 \pm 5.37(n=8)$ & $91.0 \pm 0.4 \mathrm{ab}$ \\
\hline 'IAC 18' (SE) & $66.4 \pm 3.55 \mathrm{ab}(n=10)$ & $16.5 \pm 1.59(n=18)$ & $83.0 \pm 5.0 \mathrm{abc}$ \\
\hline L $1-1-01(\mathrm{~L})$ & $66.2 \pm 1.50 \mathrm{ab}(n=10)$ & $10.3 \pm 1.86(n=10)$ & $88.0 \pm 4.0 \mathrm{ab}$ \\
\hline 'IAC 24' (SE) & $64.1 \pm 2.28 \mathrm{ab}(n=10)$ & $20.1 \pm 3.30(n=11)$ & $95.0 \pm 3.0 \mathrm{a}$ \\
\hline 'IAC 19' (L) & $59.6 \pm 0.00 \mathrm{ab}(n=1)$ & $12.0 \pm 0.00(n=1)$ & $93.0 \pm 3.0 \mathrm{a}$ \\
\hline 'IAC 17’ (E) & $59.0 \pm 3.19 \mathrm{abc}(n=10)$ & $12.6 \pm 2.22(n=18)$ & $89.0 \pm 4.0 \mathrm{ab}$ \\
\hline PI 274453 (L) & $49.6 \pm 3.78$ bc $(n=8)$ & $6.7 \pm 1.51(n=8)$ & $65.0 \pm 1.2 \mathrm{c}$ \\
\hline PI 227687 (SE) & $40.8 \pm 0.00 \mathrm{c}(n=1)$ & $9.0 \pm 0.00(n=1)$ & $71.0 \pm 6.0 \mathrm{c}$ \\
\hline PI 274454 (L) & - & - & $91.0 \pm 4.0 \mathrm{ab}$ \\
\hline$P$ & $<0.001$ & 0.058 & 0.003 \\
\hline
\end{tabular}

${ }^{a} \mathrm{E}=$ early; $\mathrm{SE}=$ semiearly; $\mathrm{L}=$ late.

${ }^{b}$ Means followed by the same lowercase letter per column do not significantly differ by LSD test $(P \leq 0.05)$.

${ }^{c} n=$ number of evaluated insects.

'IAC 23', PI 171451, IAC 74-2832, IAC 78-2318, and 'Conquista' caused higher body weight gain. No differences were found among genotypes regarding adult longevity, which ranged from 6.7 to 21.0 d. Egg viability varied from 65 to $95 \%$ among genotypes, with PI 274453 and PI 227687 yielding lower egg viabilities of 65 and $71 \%$, respectively, compared to other genotypes.

\section{Discussion}

In this study, the total length of the nymphal period (N1-N5) varied from 24.1 to $34.3 \mathrm{~d}$ among different soybean genotypes (Table 2). The fact that nymphs fed on L1-1-01 (34.3), 'IAC 100' (34.2), 'IAC 23' (31.2), and 'Coodetec 208' (30.8) showed a prolonged developmental period, suggests antibiosis/antixenosis resistance. Compared to the data obtained by Costa et al. (1998), these data demonstrate that nymphal development is directly related to the type and quality of the food consumed during the immature stage.

The similar nymphal developmental time on L1-1-01 and 'IAC100 ' might be related to the genealogy of these genotypes; L1-1-01 is a parent, whereas 'IAC 100' is a source of resistance to the stink bug complex and has been used in studies as a standard genotype resistant to defoliators (McPherson and Buss 2007) and sucking insects (McPherson et al. 2007). Thus, it is possible that L1-1-01 inherited genes that confer resistance against nymphs of E. heros. In addition to the potential presence of chemical and/or antinutritive factors that confer resistance, morphological factors may affect nymphal feeding behavior, such as elevated trichome density as previously reported (Silva et al. 2014). The increased presence of trichomes, although not seemingly affecting adult feeding behavior, probably acts as a physical barrier to nymphs in the initial (second and third instar) instar. The genotype 'IAC 100' has been explored as a source of multiple resistance against pest insects. In addition to these characteristics, it shows low foliar retention, low presence of spots in seeds even during high infestation of stink bugs, and large yield of seeds. These traits make it a potential source of resistant characteristics against damage caused by insects (Pinheiro et al. 2005, McPherson and Buss 2007, McPherson et al. 2007, Souza et al. 2015).
Regarding PI 274454, the elevated mortality in the fourth-instar $(100 \%)$ indicates significant levels of antibiosis/antixenosis. Similar results with this genotype have been reported for Nezara viridula (L.) (Hemiptera: Pentatomidae) (Piubelli et al. 2003), which might be related to the high levels of genistein, a flavonoid that confers resistance of soybean against insects (Piubelli et al. 2005, HoffmannCampo et al. 2006). In field studies, PI 274454 also exhibited resistance to defoliators (Lourenção et al. 1985) and sucking insects (Rossetto et al. 1986). Therefore, this genotype is characterized by multiple resistance, which is useful in soybean breeding programs.

The genotype PI 227687, which exhibits multiple resistance against soybean pests (Kogan 1989), did not affect nymphal developmental time of E. heros (24.1). This genotype did not prolong the nymph development of Piezodorus guildinii (Westwood) (Hemiptera: Pentatomidae) (Silva et al. 2013). In addition, it was also susceptible to biotype B of Bemisia tabaci (Genn.) (Hemiptera: Aleyrodidae) (Lima and Lara 2004). However, PI 227687 did cause high E. heros nymphal mortality (only $2 \%$ of the nymphs complete development). Other studies have also reported high nymphal mortality of N. viridula fed with this genotype (Piubelli et al. 2003).

Based on nymphal viability, adult emergence occurred in all genotypes except for PI 274454. Genotypes 'IAC 19', PI-227687, and PI 229358 resulted in less than $10 \%$ nymphal viability, which suggests levels of antibiosis and/or antixenosis. It is possible that this resistance is associated with the presence of antinutritional compounds and/or secondary compounds that negatively affect nymphal development (Smith 2005). Nymphal viability, which ranged from 0 to $60 \%$, was significantly lower than that in a study performed by Cividanes and Parra (1994), who found greater than $90 \%$ viability on green pods of 'Paraná' and 'Cristalina', on matured seeds of 'Paraná', and on the peanut genotype 'Tatu Vermelho'.

Adults originating from nymphs that fed on genotypes PI 227687 and PI 274453 showed the lowest body weights. These results are similar to those observed for $N$. viridula, which presented low adult body weight after feeding on PI 227687 (Piubelli et al. 2003). Low insect weight might be associated with low lipid concentrations in these genotypes; as a result, stink bugs use their accumulated 
nutritional reserves during the nymphal stages, consequently reaching lower adult body weights (Panizzi et al. 1989). PI 227687, which was also characterized by high nymphal mortality and low body weight, also negatively affected egg viability, indicating that this genotype can potentially be used to develop soybean resistance to E. heros.

According to the results obtained in this study, the genotypes L1-1-01, 'IAC 100', 'IAC 23', 'Coodetec 208', PI 274454, 'IAC 19', PI 227687, PI 229358, and PI 274453 exhibited antibiosis/antixenosis resistance to E. heros. Due to the significance of E. heros in tropical regions, these genotypes are valuable in soybean breeding programs that aim to develop genotypes resistant to this species, which can reduce populations of $E$. heros in association with further pest management techniques.

\section{Acknowledgments}

We acknowledge CAPES for the doctoral scholarship granted to the first author. We would also like to thank the Agronomic Institute of Campinas for supplying the seeds of the soybean genotypes.

\section{References Cited}

Belo, M. S., W. Pignati, E. F. G. C. Dores, J. C. Moreira, and F. Peres. 2012. Uso de agrotóxicos na produção de soja do Estado do Mato Grosso: um estudo preliminar de riscos ocupacionais e ambientais. Rev Bras Saude Ocup. 37:78-88.

Bueno, A. F., M. J. Batistela, R. C. O. F. U. Bueno, J. B. França-Neto, M. A. N. Nishikawa, and A. Libério-Filho. 2011. Effects of integrated pest management, biological control and prophylactic use of insecticides on the management and sustainability of soybean. Crop Prot. 30:937-945.

Bueno, A. F., S. V. Paula-Moraes, D. L. Gazzoni, and A. F. Pomari. 2013. Economic thresholds in soybean-integrated pest management: old concepts, current adoption, and adequacy. Neotrop. Entomol. 42:439-447.

Cividanes, F. J. and J. R. P. Parra. 1994. Biologia em diferentes temperaturas e exigências térmicas de percevejos pragas da soja. II. Euschistus heros (Fabr.) (Heteroptera: Pentatomidae). Pesq. Agropec. Bras. 29:1841-1846.

Corrêa-Ferreira, B. S. and J. Azevedo. 2002. Soybean seed damage by different species of stink bugs. Agric. For. Entomol. 4:145-150.

Costa, M. L. M., M. Borges, and E. F. Vilela. 1998. Biologia reprodutiva de Euschistus heros (F.) (Heteroptera: Pentatomidae). An. Soc. Entomol. Bras. 27:559-568.

Degrande, P. E., L. M. Vivan, M. M. Yuyama, S. Suzuki, and A. S. Camacho. 2007. Pragas da soja, pp. 150-163. In M. T. Fundação (ed.) Boletim de Pesquisa de Soja. Rondonópolis, Fundação, MT.

Depieri, R. A., and A. R. Panizzi. 2011. Duration of feeding and superficial and in-depth damage to soybean seed by selected species of stink bugs (Heteroptera: Pentatomidae). Neotrop. Entomol. 40: 197-203.

Fehr, W. R. and C. E. Caviness. 1977. Stages of soybean development. Ames, Iowa State University Cooperative Extension Service Special Report 80.

Hoffmann-Campo, C. B., J. A. Ramos Neto, M. C. N. Oliveira, and L. J. Oliveira. 2006. Detrimental effect of rutin on Anticarsia gemmatalis. Pesq. Agropec. Bras. 41:1453-1459.

Kogan, M. 1989. Plant resistance in soybean insect control, pp. 1519-1525. In A. J. Pascale (ed.) World Research Conference IV. Orientácion Gráfica Editora, Buenos Aires,

Kuss, C. C., V. D. B. Toaldo, J. Berghetti, O. H. C. Pias, R. C. R. KussRoggia, D. R. Sosa-Gómez, C. J. Basso, A. L. Santi, and S. Roggia. 2012. Percentagem de espécies de percevejos pentatomídeos ao longo do ciclo da soja no Norte do Paraná. EmbrapaWeb. http://www.cnpso.embrapa. br/download/Doc-333.pdf (Accessed 11 January 2017).

Lima, A. C. S. and F. M. Lara. 2004. Resistance of soybean genotypes to the silverleaf whitefly Bemisia tabaci (Genn.) biotype B (Hemiptera: Aleyrodidae). Neotrop. Entomol. 33:71-75.
Lara, F. M. 1991. Princípios de resistência de plantas a insetos. Ícone, São Paulo.

Lourenção, A. L., C. J. Rossetto, and M. D. Miranda. 1985. Resistência de soja a insetos. IV. Comportamento de cultivares e linhagens em relação a Hedilepta indicata (Fabr.). Bragantia 44:149-157.

Lourenção, A. L., M. A. C. Miranda, and V. Nagai. 1987. Resistance of soybean to insects. VII. Evaluation of damage to cultivars and lines by stink bugs. Bragantia 46:45-57.

Lourenção, A. L., A. S. Costa, and M. A. C. Miranda. 1989. Sources of resistance to insect pests and virus vectors in the soybean germplasm tested at the Instituto Agronômico, Brazil, pp. 1578-1581. In A.J. Pascale (ed.), World Soybean Research Conference IV. Orientación Gráfica Editora, Buenos Aires, Argentina.

Lourenção, A. L., J. C. V. N. A. Pereira, M. A. C. Miranda, and G. M. B. Ambrosano. 2000. Evaluation of damage to early maturity soybean cultivars and lines caused by stink bugs and caterpillars. Pesq. Agropec. Bras. 35:879-886.

McPherson, R. M. and G. R. Buss. 2007. Evaluating lepidopteran defoliation resistance in soybean breeding lines containing the stink bug (Hemiptera: Pentatomidae) resistance IAC-100 cultivar in their pedigrees. J. Econ. Entomol. 100: 962-968.

McPherson, R. M., G. R. Buss, and P. M. Roberts. 2007. Assessing stink bug resistance in soybean breeding lines containing genes from germplasm IAC-100. J. Econ. Entomol. 100:1456-1463.

Miranda, M. A. C., N. R. Braga, A. L. Lourenção, F. T. S. Miranda, S. H. Uneda, M. F. Ito. 2003. Description, yield and stability of early soybean insect resistance cultivar IAC 24. Bragantia 62: 29-37.

Mourão, A. P. and A. R. Panizzi. 2000. Estágios ninfais fotossensíveis à indução da diapausa em Euschistus heros (Fabr.) (Hemiptera: Pentatomidae). An. Soc. Entomol. Bras. 29: 219-225.

Panizzi, A. R. 1997. Wild hosts of Pentatomids: ecological significance and role in their pest status on crops. Annu. Rev. Entomol. 42: 99-122.

Panizzi, A. R. 2007. Nutritional ecology of plant feeding arthropods and IPM, pp. 170-222. In M. Kogan and P. Jepson (eds.), Perspectives in Ecological Theory and Integrated Pest Management. Cambridge University Press, Cambridge, UK.

Panizzi, A. R. and J. R. P. Parra. 1991. Ecologia nutricional de insetos e suas implicações no manejo de pragas. Manole, Brasília.

Panizzi, A. R. and F. A. C. Silva. 2009. Insetos sugadores de sementes (Heteroptera), pp. 465-522. In A. R. Panizzi and J. R. P. Parra (eds.), Bioecologia e nutrição de insetos. Embrapa, Brasília.

Panizzi, A. R., A. M. Meneguim, and M. C. Rossini. 1989. Impacto da troca de alimento da fase ninfal para a fase adulta e do estresse nutricional na fase adulta na biologia de N. viridula (Hemiptera: Pentatomidae). Pesq. Agropec. Bras. 24: 945-954.

Pinheiro, J. B., N. A. Vello, C. J. Rossetto, and M. I. Zucchi. 2005. Potential of soybean genotypes as insect resistance sources. Crop. Breed. Appl. Biotechnol. 5: 294-301.

Piubelli, G. C., C. B. Hoffmann-Campo, I. C. Arruda, and F. M. Lara. 2003. Nymphal development, lipid content, growth and weight gain of Nezara viridula (L.) (Heteroptera: Pentatomidae) fed on soybean genotypes. Neotrop. Entomol. 32: 127-132.

Piubelli, G. C., C. B. Hoffmann-Campo, F. Moscardi, S. H. Miyakubo, and M. C. de Oliveira. 2005. Are chemical compounds important for soybean resistance to Anticarsia gemmatalis? J. Chem. Ecol. 31: 1509-1524.

Rossetto, C. J., T. Igue, M. A. C. Miranda, and A. L. Lourenção. 1986. Resistance of soybean to insects: VI. Performance of varieties in relation to stink bugs. Bragantia 45: 323-335.

Saluso, A., L. Xavier, F. A. C. Silva, and A. R. Panizzi. 2011. An invasive pentatomid pest in Argentina: neotropical brown stink bug, Euschistus heros (F.) (Hemiptera: Pentatomidae). Neotrop. Entomol. 40: 704-705.

SAS Software. 2001. SAS/STAT: User's guide, version 8.1. SAS Institute, Cary, North Carolina.

Silva, F. A. C. and A. R. Panizzi. 2007. Cotton balls as oviposition substrate for laboratory rearing of phytophagous stink bugs (Heteroptera: Pentatomidae). Ann. Entomol. Soc. Am. 100: 745-748. 
Silva, F. A. C., J. J. Silva, R. A. Depieri, and A. R. Panizzi. 2012a. Feeding activity, salivary amylase activity, and superficial damage to soybean seed by adult Edessa meditabunda (F.) and Euschistus heros (F.) (Hemiptera: Pentatomidae). Neotrop Entomol 41: 386-390.

Silva, J. P. G. F., E. L. L. Baldin, E. S. Souza, and A. L. Lourenção. 2012b. Assessing Bemisia tabaci (Genn.) biotype B resistance in soybean genotypes: antixenosis and antibiosis. Chil J Agr Res 72: 516-522.

Silva, J. P. G. F., E. L. L. Baldin, E. S. Souza, V. F. Canassa, and A. L. Lourenção. 2013. Characterization of antibiosis to the redbanded stink bug Piezodorus guildinii (Hemiptera: Pentatomidae) in soybean entries. J. Pest. Sci. 86: 649-657.

Silva, J. P. G. F., E. L. L. Baldin, V. F. Canassa, E. S. Souza, and A. L. Lourenção. 2014. Assessing antixenosis of soybean entries against Piezodorus guildinii (Hemiptera: Pentatomidae). Arthropod. Plant Interact. 8: 349-359.

Smaniotto, L. F. and A. R. Panizzi. 2015. Interactions of selected species of stink bugs (Hemiptera: Heteroptera: Pentatomidae) from leguminous crops with plants in the Neotropics. Fla. Entomol. 98: 7-17.
Smith, C. M. 2005. Plant Resistance to Arthropods. Springer, Berlin, Germany. Smith, C. M. and S. L. Clement. 2012. Molecular bases of plant resistance to arthropods. Annu. Rev. Entomol. 57: 309-328.

Sosa-Gómez, D. R. and F. Moscardi. 1995. Retenção foliar diferencial em soja provocada por percevejos (Heteroptera: Pentatomidae). An. Soc. Entomol. do Brasil 24: 414-404.

Sosa-Gómez, D. R. and J. J. Silva. 2010. Neotropical brown stink bug (Euschistus heros) resistance to methamidophos in Paraná, Brazil. Pesq. Agropec. Bras. 45: 767-769.

Souza, E. S., E. L. L. Baldin, and T. L. M. Fanela. 2012. Desenvolvimento de Nezara viridula (L. 1758) (Hemiptera: Pentatomidae) em genótipos de soja. Boletin Sanidad Vegetal Plagas 38: 41-49.

Souza, E. S., J. P. G. F. Silva, E. L. L. Baldin, C. G. Pierozzi, L. S. Cunha, V. F. Canassa, L. E. R. Pannuti, and A. L. Lourenção. 2015. Response of soybean genotypes challenged by a stink bug complex (Hemiptera: Pentatomidae). J. Econ. Entomol. 109: 898-906.

Valle, G. E. and A. L. Lourenção. 2002. Resistance of soybean genotypes to Bemisia tabaci (Genn.) biótipo B (Hemiptera: Aleyrodidae). Neotrop. Entomol. 31: 285-295. 